\title{
Effect of Temperature and Seasonality Principal Epizootiological Risk Factor on Vibriosis and Photobacteriosis Outbreaks for European Sea Bass in Greece (1998-2013)
}

\author{
Georgios Bellos $^{1 *}$, Panagiotis Angelidis ${ }^{2}$ and Helen Miliou ${ }^{1}$ \\ ${ }^{1}$ Department of Applied Hydrobiology, Faculty of Animal Science and Aquaculture, Agricultural University of Athens, GR-11855 Athens, Greece \\ ${ }^{2}$ Laboratory of Ichthyology, Faculty of Veterinary Medicine, Aristotle University of Thessaloniki, GR-54124 Thessaloniki, Greece
}

\begin{abstract}
Our epizootiological survey was focused on bacterial diseases of European sea bass, Dicentrarchus labrax L., an important Mediterranean species for aquaculture, in Greece. Vibriosis and Photobacteriosis were the most severe bacterial diseases, located in the majority of Greek mariculture areas (Argolikos gulf, North Evoic gulf Maliakos gulf and Thesprotia Sagiada coast, Amvrakikos gulf, Aitoloakarnania Mitikas coast, lonian island coasts) during the period 1998-2013. A database of 152 cases was formulated, from which 134 cases concerned vibriosis and photobacteriosis, while the rest outbreaks were motile aeromonas septicemia and tenacibaculosis. PCA pointed out three principal components with the following ranking order: a) temperature and seasonality, b) group of mariculture areas and average body weight, and c) case year. The results of logistic analysis showed the temperature seasonality as the first, in ranking, and the only statistically significant epizootiolological risk factor. Contrast Test (low vs. high temperature values) also proved the significant effect of temperature $(p<0.05)$. Vibriosis pathogen Listonella (Vibrio) anguillarum was recorded in a wide temperature range $\left(12-26^{\circ} \mathrm{C}\right)$ in the most of Greek rearing locations. In contrast, Vibriosis from rest vibria was found to a narrow temperature range, especially in Argolikos gulf, North Evoic gulf and Ionian Island coasts. Specifically, V. harveyi cases emerged at high temperatures $\left(19-22^{\circ} \mathrm{C}\right)$, while those of $V$. alginolyticus and $V$. splendidus II at low temperatures $\left(15-17^{\circ} \mathrm{C}\right)$. Photobacterium damselae subspecies piscicida in most of Greek rearing areas and Photobacterium damselae subspecies damselae in Argolikos gulf, North Evoic gulf and Ionian Island coasts appeared in a relatively wide range $\left(19-25^{\circ} \mathrm{C}\right)$. However, they showed higher frequencies in warm period. The results will support an evolutionary epizootiological survey and will reinforce a preventive biosecurity program in Greek mariculture taking into consideration the temperature - seasonality factor along with the classical sanitary approach.
\end{abstract}

Keywords: Epizootiological survey; Risk factors; Vibrial diseases; Sea bass; Aquaculture; Greece; Preventive biosecurity

\section{Short Communication}

European sea basis [1] commonly known as "sea bass" in Mediterranean and European Union countries, is one of the most commercially important, mainly brackish and seawater fish species. It is characterized by the second higher global production amount of 48,000 tons in Greece in comparison with the Turkish highest production amount of 51,600 tons, in 2013 [2]. In Greece, as in other Mediterranean countries, mariculture is a dynamic aquaculture sector with an also intensive development of hatchery tanks and cage culture in Spain, Italy and France [3]. The hatchery production establish Greece as the most significant provider with a production amount of 192,000 thousand sea bass juveniles, not only nationally, but also for other Mediterranean countries, in 2013 [2]. European sea bass was the target fish species of our research with emphasis on causal pathogen agents, geographic distribution of their incidences through this epizootiological survey, for a long period 1998-2013. It has focused on clear case results, for the assessment of the epizootiological risk factors in most important coastline rearing areas in Greece. Similarly, epizootiological surveys have been performed in other Mediterranean or European countries, especially in France and Spain [4,5]. The Greek coastline most important mariculture locations of this survey consist of four Mediterranean fish culture area groups with approval from Greek Government Authorities have as follow: a) Thesprotia Sagiada and Mitikas gulf - Ionian Island coasts (Ionian Sea), b) West - Central East Amvrakikos gulf (Ionian Sea), c) Maliacosgulf -- Biotia - Evoia (North Evoic gulf) (Central Aegean Sea) d) Argolicos gulf - (South Aegean Sea). A database of 152 cases of severe bacterial diseases, for
European sea bass, was formulated. The 134 cases concerned vibriosis and photobacteriosis outbreaks caused from the pathogen bacteria shown (Figure 1). The rest 18 cases concerned motile aeromonas septicemia and tenacibaculosis (former marine flexibacteriosis) caused from Aeromonas hydrophila, A. sobria, Aeromonas spp. and Tenacibaculum maritimum (former Flexibacter maritimus). The 152 cases were classified into groups according to: a) temperature as low $\left(11-19^{\circ} \mathrm{C}\right)$ and high $\left(20-28^{\circ} \mathrm{C}\right)$ values, b) seasonality as winter (December - February), spring (March - May), summer (June August) and autumn (September - November), c) the above area groups of Greek coastline, $\mathrm{d}$ ) average body weight as $0.1-5 \mathrm{~g}$ (immature innate non-specific immunity and almost absent specific acquired immunity class of larvae and juveniles), 6-80 g (mature innate and immature acquired immunity class of elder juveniles), 81-150 g (mature innate non-specific and mature acquired specific immunity class of young fish), 151-400 g (mature innate non-specific and mature acquired specific immunity of adult fish), and e) case-year from the

*Corresponding author: Georgios Bellos, Department of Applied Hydrobiology, Faculty of Animal Science and Aquaculture, Agricultural University of Athens, GR11855 Athens, Greece, Tel: 923326-022624; E-mail: elenmi@aua.gr

Received March 17, 2015; Accepted April 08, 2015; Published May 30, 2015

Citation: Bellos G,Angelidis P, Miliou H (2015) Effect of Temperature and Seasonality Principal Epizootiological Risk Factor on Vibriosis and Photobacteriosis Outbreaks for European Sea Bass in Greece (1998-2013). J Aquac Res Development 6: 338 doi:10.4172/2155-9546.1000338

Copyright: $\odot 2015$ Bellos G, et al. This is an open-access article distributed under the terms of the Creative Commons Attribution License, which permits unrestricted use, distribution, and reproduction in any medium, provided the original author and source are credited. 
Citation: Bellos G, Angelidis P, Miliou H (2015) Effect of Temperature and Seasonality Principal Epizootiological Risk Factor on Vibriosis and Photobacteriosis Outbreaks for European Sea Bass in Greece (1998-2013). J Aquac Res Development 6: 338. doi: 10.4172/2155-9546.1000338

Page 2 of 3

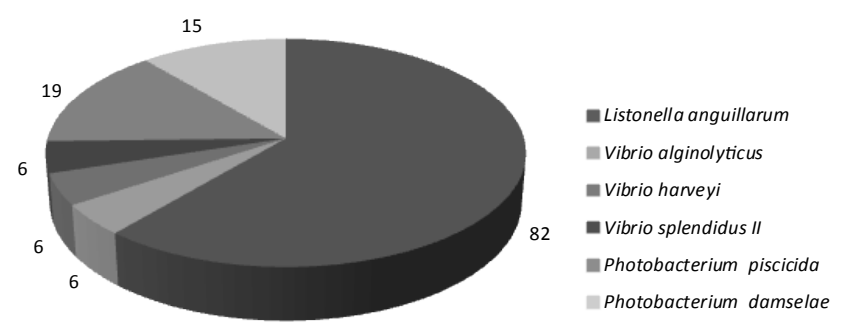

Figure 1: The Vibriosis and photobacteriosis cases pie for sea bass (1998-2013).

period (1998-2013). PCA pointed out three principal components with the following ranking order: a) temperature and seasonality, b) group area and average body weight, and c) case year. In a following Logistic Procedure, the two first principal components were considered. The results of logistic analysis showed the temperature - seasonality as the first, in ranking, and the only statistically significant epizootiological risk factor $(\mathrm{p}<0.05)$. Contrast Test [6] with temperature as the only variable (low vs. high temperature values), also proved the significant effect of this risk factor $(\mathrm{p}<0.05)$. Statistical analysis was performed with SAS [7]. In this survey, the sea bass classical vibriosis outbreaks from Listonella anguillarum appeared in a wide temperature value range $\left(12-26^{\circ} \mathrm{C}\right)$. However, the acute classical vibriosis affected larvae and juveniles mainly at high temperatures, while the chronic or asymptomatic form appeared in young and adult fish at low temperatures. The chronic form skin ulcerative and visceral or intestinal of classical vibriosis has been reported only for adult fish at low temperatures in Greek coastline areas [8,9]. Larsen [10] reported that L. anguillarum can survive, not only in winter but also in summer, reaching a maximum population number. It has been suggested that vibriosis appears when the water temperature exceeds $10-12^{\circ} \mathrm{C}$ and occurs more often in areas where overcrowding exists and environmental equilibrium is fragile [11]. Outbreaks from Vibrio harveyi were recorded for the acute vibriosis form in juveniles at $19^{\circ} \mathrm{C}$ in May with high losses and for the sub-acute intestinal and visceral vibriosis in adult fish, at $22^{\circ} \mathrm{C}$ in August. Incidences from $V$. harveyi have also been reported for sea bass, at similar temperature values, in North Ionian Sea (South Italy) [12]. Contrary to the above, vibriosis from Vibrio alginolyticus and V. splendidus sero-type II outbreaks were recorded at low temperatures $15-17^{\circ} \mathrm{C}$ (November - February) in both juveniles and adults, causing higher mortalities in the former. Similarly, cases from $V$. alginolyticus have been reported for sea bass at low temperature values in Adriatic Sea (North Italy) and North Ionian Sea (South Italy) [12]. The photobacteriosis outbreaks from Photobacterium damselae subspecies pisci-cida (former Pasteurella piscicida) emerged at temperature values $19-25^{\circ} \mathrm{C}$ (April -September). At this temperature range, cases from sea bass juveniles and young fish with acute septicemia epizootics in Amvrakikos and Argolikos gulf have been reported [9,1315]. In addition, chronic visceral or asymptomatic photobacteriosis cases have been referred to adult fish in Mediterranean coasts of Turkey $[16,17]$ Egypt [18] Italy [19] and Spain [2]. Other researchers [3,20] have identified photobacteriosis epizootics mainly in summer, after heavy rain falls in brackish water coast areas, with high losses. The motile Photobacterium damselae subspecies damselae, in our survey, was found in sea bass at a temperature value range $19-24,5^{\circ} \mathrm{C}$ (May August). Specifically, chronic or asymptomatic photobacteriosis cases appeared in adults at $19^{\circ} \mathrm{C}$, while acute septicemic photobacteriosis outbreaks with high losses in juvenile and young fish at $21-24.5^{\circ} \mathrm{C}$, particularly under stress conditions caused by cages transportation. This newer motile subspecies has been detected in Italy and Spain coasts from sea bass at high temperature values [21-24]. All the above data for the principal epizootiological risk factor, temperature and seasonality, effect on vibriosis and photobacteriosis, for European sea bass, may be utilized to an innovative marine biosecurity program. It can be applied especially for the stenothermal vibria like $V$. harveyi and $V$. alginolyticus and V. splendidus serotype II. For the eurythermal vibrio L. anguillarum a preventive medicine procedure has recently been applied in Greece for sea bass, including probiotics and immunostimulants administration to larvae $(0.1 \mathrm{~g})$, bath vaccinations of L. anguillarum serotypes $\mathrm{O} 1$ and $\mathrm{O} 2$ to $2 / 5 \mathrm{~g}$ and intraperitoneal vaccination to $25 \mathrm{~g}$ juveniles $[10,25,26]$. A bivalent bacterin vaccine for the protection from both classical vibriosis and photobacteriosis has also been applied, particularly in areas with higher water temperatures [27]. A further research is needed for vaccination procedures concerning vibriosis from the rest vibria. In these vaccination programs, the role of temperature seasonality should be taken into consideration. In addition, the rearing temperature adjustment at adverse levels for each stenothermal Vibrio sp. can be applied where this is feasible, such as in recirculating aquaculture systems. Specifically, the up-to-date data point out optimum temperatures low (e.g. $\left.<19^{\circ} \mathrm{C}\right)$ for V. harveyi and high (e.g. $\left.>17^{\circ} \mathrm{C}\right)$ for $\mathrm{V}$. alginolyticus and V. splendidus serotype II. It seems that rearing of sea bass at a temperature about $18^{\circ} \mathrm{C}$ prevents main health problems related to Vibrio pathogens. Therefore, under such preventive veterinary medicine biosecurity conditions, we can reinforce the sustainability and profitability through continual epizootiological survey and strict surveillance.

\section{Acknowledgments}

We are grateful to the Associate Professor Dr. Antonios Kominakis (Department of Animal Husbandry, Faculty of Animal Science and Aquaculture, Agricultural University of Athens) and the Lecturer Dr. Nikolaos Demiris (Department of Statistics, Athens University of Economics and Business) for their contribution to statistical analysis.

\section{References}

1. Athanassopoulou F, Billinis C, Psychas V, Karipoglou K (2003) Viral encephalopathy and retinopathy of Dicentrarchus labrax (L.) farmed in fresh water in Greece. J Fish Dis 26: 361-365.

2. Jung TS, Thompson KD, Morris DJ, Adams A, Sneddon K (2001) The production and characterization of monoclonal antibodies against Photobacterium damselae ssp. piscicida and initial observations using immunohistochemistry. J Fish Dis 24: 64-77.

3. Toranzo AE, Magariños B, Romalde $J L$ (2005) A review of the bacterial fish diseas-es in mariculture systems. Aquaculture 246: 37-61.

4. Davies IM, Barg U, Black E (2004) GESAMP Initiative on Environmental Risk Analysis for Coastal Aquaculture.

5. De Blas N (2005) Searching for Evidence of Pathogen Exchange in Aquatic Environ-ments: Limits of Epidemiological Tools.

6. Abdi H, Williams LJ (2010) Contrast analysis.

7. SAS (2010) SAS/STAT@ 9.22 User's Guide. SAS Institute Inc, Campus Drive, Cary, North Carolina, USA.

8. Noussias H (2007) Vibriosis (Vibrio spp.) in Fish Farms.

9. Alexopoulos A, Plessas S, Voidarou C, Noussias H, Stavropoulou E, et al. (2011) Microbial ecology of fish species ongrowing in Greek sea farms and their watery environment. Anaerobe 17: 264-266.

10. Larsen JL (1982) Vibrio anguillarum: prevalence in three carbohydrate loaded marine recipients and a control. Zentralbatt fur Bakteriologie und Hygiene 1, Abteilung Orig-inale C 3: 519-530.

11. Angelidis $P$ (2014) Chapter 11: Vibrio anguillarum-associated vibriosis in the Mediter-ranean aquaculture. Blue Crab PC Publication, Chalastra, Greece. 
Citation: Bellos G, Angelidis P, Miliou H (2015) Effect of Temperature and Seasonality Principal Epizootiological Risk Factor on Vibriosis and Photobacteriosis Outbreaks for European Sea Bass in Greece (1998-2013). J Aquac Res Development 6: 338. doi: $10.4172 / 2155-9546.1000338$

12. Cavallo RA, Stabili L (2004) Culturable vibrios biodiversity in the Northern Ionian Sea (Italian coasts). Scientia Marina 68: 23-29.

13. Bakopoulos V, Hanif A, Poulos K, Galeotti M, Adams A, et al. (2003) The effect of in vivo growth on the cellular and extracellular components of the ma-rine bacterial pathogen Photobacterium damselae subsp. piscicida. J Fish Dis 27: 1-13.

14. Bakopoulos V, Pearson M, Volpatti D, Gusmani L, Adams A, et al. (2004) Investigation of media formulations promoting differential antigen expression by Photobacterium damselae ssp. piscicida and recognition by sea bass, Dicentrarchus labrax (L.), immune sera. J Fish Dis 26: 1-13.

15. Yiagnisis M, Athanassopoulou F (2011) Bacteria Isolated from Diseased Wild and Farmed Marine Fish in Greece.

16. Candan G, Ang Kucker M, Karatas S (1996) Pasteurellosis in cultured sea bass (Dicentrarchus labrax) in Turkey. Bulletin of the European Association of Fish Pathologists16: 150-153.

17. Korun J, Timur G (2005) The first Pasteurellosis case in cultured sea bass (Dicen-trarchuslabrax L.) at low marine water temperatures in Turkey. The Israeli Journal of Aquaculture - Bamidgeh 57: 197-206

18. Almeida A, Cunha Â, Gomes N, Alves E, Costa L, et al. (2009) Phage therapy and photodynamic therapy low environmental impact approaches to inactivate microorganisms in fish farming plants. Marine Drugs $7: 268-313$.

19. Zappulli V, Patarnello T, Patarnello P, Frassineti F, Franch R, et al. (2005) Direct identification of Photobacterium damselae subspecies piscicida by PCRRFLP analysis. Dis Aquatic Organ 65: 53-61.
20. Magariños B, Couso N, Noya M, Merino P, Toranzo AE, et al. (2001) Effect of temperature on the development of pasteurellosis in carrier gilthead seabream (Spa-rus aurata). Aquaculture 195: 17-21.

21. Osorio C, Toranzo AE, Romalde JL, Barja JL (2000) Multiplex PCR assay for ureC and $16 \mathrm{~S}$ rRNA genes clearly discriminates between both subspecies of Photo-bacterium damselae. Dis Aquatic Organ 40: 177-183.

22. Botella S, Pujalte MJ, Macián MC, Ferrús MA, Hernández J, et al. (2002) Amplified fragment length polymorphism (AFLP) and biochemical typing of Photo-bacterium damselae subsp. damselae. J App Microbiol 93: 681-688.

23. Rayan PR, Lin JHY, Ho MS, Yang HL (2003) Simple and rapid detection of Photobacterium damselae ssp. piscicidab y a PCR technique and plating method. J App Microbiol 95: 1375-1380.

24. Labella A, Vida M, Alonso MC, Infant C, Cardenas S, et al. (2006) First isolation of Photobacterium damselae ssp. damselaefrom cultured redbanded seabream, Pagrusauriga Valenciennes, in Spain. J Fish Dis 29: 175-179.

25. Costello MJ, Grant A, Davies IM, Cecchini S, Papoutsoglou S, et al. (2001) The control of chemicals used in aquaculture in Europe. J App Ichthyol 17: 173-180.

26. Angelidis $\mathrm{P}$, Karagiannidis D, Crump EM (2006) Efficacy of Listonella anguillarum (syn. Vibrio anguillarum) vaccine for juvenile sea bass Dicentrarchus labrax. Diseases of Aquatic Organisms 71: 19-24.

27. Athanassopoulou F (2006) Diseases of Marine Fish. University of Thessaly Volos, Greece. 